Research Article

\title{
Inhibitory Potentials of Ethanol Extract of Nymphaea nauchali against Experimentally Induced Ulcers in Wistar Rats
}

\author{
Poornachandra C ${ }^{1}$, Ramesh $C^{1}$, Shabana $S^{2}$, Pinkey Rawal ${ }^{3}$, Soma Pramanik ${ }^{3}$ \\ ${ }^{1}$ Department of Pharmaceutical Chemistry, East West College of Pharmacy, Bangalore, Karnataka, India. \\ ${ }^{2}$ Department of Pharmacognosy, East West College of Pharmacy, Bangalore, Karnataka, India. \\ ${ }^{3}$ Department of Pharmacology, East West College of Pharmacy, Bangalore, Karnataka, India. \\ *Corresponding author's E-mail: poornachandracewcp@gmail.com
}

Received: 03-08-2021; Revised: 26-09-2021; Accepted: 04-10-2021; Published on: 15-10-2021.

\begin{abstract}
The current investigational work was designed to evaluate inhibitory effect of ethanol extract of Nymphaea nauchali against experimentally induced ulcers in albino wistar rats. The aerial parts of Nymphaea nauchali were dried under shade, powdered and deffated with petroleum ether and then marc left over was subjected to ethanol extraction using soxhlet apparatus. Antiulcer activity of ethanol extract was determined against ethanol induced and aspirin induced ulcers in experimental animal models. The total number of ulcers formed, ulcer index, percentage inhibition, ulcerated area, protected area, $\mathrm{pH}$ and Total acidity were parameters in the study. The ethanol extract of Nymphaea nauchali have significantly reduced the total number of ulcers formed, ulcer index, ulcerated area and total acidity in therapeutic groups compare to vehicle control and there by significantly increased percentage inhibition of ulcers and protected area which was evident by significant rise in $\mathrm{pH}$ of gastric content. The effect of extracts was dose dependent and results were comparable to that of standard drug omeprazole. The results obtained from the present work suggest that the ethanol extract of Nymphaea nauchali possess significant anti-ulcer potentials against experimentally induced ulcers in albino rats.
\end{abstract}

Keywords: Nymphaea nauchali, Anti-ulcer activity, Ethanol, Aspirin, Ulcer index, pH, total acidity, Percentage inhibition and percentage of protected area.

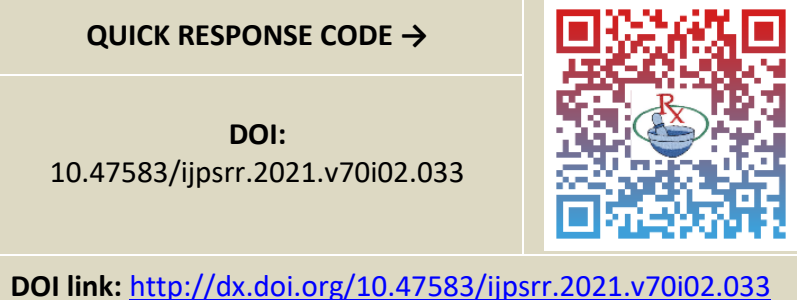

\section{INTRODUCTION}

$\mathrm{P}$ eptic ulcer which includes both gastric and duodenal ulcers is one of the most prevalent gastrointestinal tract diseases that affect a wide range of people worldwide ${ }^{1}$. Due to its high morbidity and mortality rates, peptic ulcer disease has been one of the leading causes of gastrointestinal surgery over a century. The pathophysiology of peptic ulcer disease was attributed to the imbalance between the offensive factors (e.g. acid, pepsin, Helicobacter infection) and the defensive ones (e.g. bicarbonate, mucin, prostaglandins, nitric oxide and growth factors) ${ }^{2}$. The use of non-steroidal antiinflammatory drugs (NSAIDs), irregular diet, emotional stress, excessive alcohol use and smoking are all the principal etiological factors associated with the peptic ulcer $^{3}$. Nowadays, the drug treatment of ulcer is commonly focused on the suppression of acid secretion and the enhancement of gastric protection ${ }^{4}$. However, more and more clinical evaluation on the drug treatment showed that tolerance was developed and also incidence of relapses as well as side effects were increased, which made the efficacy of the treatment be arguable. Many of the existed medicines have limitations, especially when they were used against the ulcers with complex etiologies ${ }^{4}$.

The aim of treating peptic ulcer disease is to relieve pain, heal the ulcer and prevent ulcer recurrence. Currently, efforts are on research of a suitable treatment from natural product sources. A large number of species and herbs have been evaluated by various researchers for their anti-ulcer effects to achieve a favourable outcome ${ }^{5}$. A wide range of drug is currently available for the treatment of gastric ulcer which includes proton pump inhibitor, $\mathrm{H}_{2}$ blocker, antacid, and anti-cholinergic. The most common adverse effect of these drugs are hypergastrinemia, hypersensivity, gynecomastia, impotence, arrhythmia and blood dyscaris such as thrombocytopenia and enteric infection (Clostridium deficile) ${ }^{6}$. Hence till now there is no truly satisfactory medicine for the management of peptic ulcer and plant drugs are proven as effective and safe drugs for the management ulcers ${ }^{6}$. About 600 commercial preparations with claimed liver protecting activity are available all over the world. About 100 Indian medicinal plants belonging to 40 families are used for herbal formulation?

Nymphaea nouchali also known as Nymphaea stellata belongs to family Nymphaeaceae is an important and well-known medicinal plant, widely used in the Ayurveda and Siddha systems of medicines for the 
treatment of diabetes, inflammation, ulcers, liver disorders, urinary disorders, menorrhagia, blenorrhagia, menstruation problem, as an aphrodisiac, and as a bitter tonic ${ }^{8.9}$. Though Nymphaea nouchali widely used for the management of peptic ulcer in traditional and folklore medicine but doesn't have the scientific evidence for the same ${ }^{10}$. Hence the present study was designed to assess the antiulcer activity of the Nymphaea nauchali against animal models of ulcer with the objective to provide establish the scientific rationale.

\section{MATERIALS AND METHODS}

\section{Preparation of ethanol extract}

The areal parts of Nymphaea nauchali have been collected from surroundings of Bangalore and authenticated. The authenticated plant material was dried under shade and dried plant material was pulverized into powder and sieved through No. 22 mesh. About $350 \mathrm{~g}$ (appx.) of coarse powder was subjected to successive solvent extraction using petroleum ether, benzene, chloroform and ethanol in soxhlet apparatus ${ }^{11}$.

Preliminary phytochemical investigation of ethanol extract of Nymphaea nauchali

The preliminary phytochemical investigation for the ethanol extract of Nymphaea nauchali had been conducted as per procedure prescribed by Khandelwa ${ }^{12}$.

\section{Drugs and chemicals}

All the chemical and reagents used in the present study were of analytical grade and procured from following sources. The inducing agents eethanol and aspirin were obtained from Sigma-aldrich chemicals Pvt. Ltd., Bangalore and Tween80 was obtained from Nice chemicals Bangalore. All the other solvents and chemicals used for extraction and physiochemical investigation were as of analytical grade purchased from S.D fine chemicals Pvt. Ltd. Bangalore.

\section{Animals}

Albino wistar rats of either sex (150-200g) will acclimatized for seven days under standard husbandry conditions, i.e.; room temperature of $25 \pm 1^{\circ} \mathrm{C}$; relative humidity $45-55 \%$ and a $12: 12 \mathrm{~h}$ light/ dark cycle. The animals had to free access to standard rat pellet, with water supplied ad libitum under strict hygienic conditions. Animals were habituated to laboratory conditions for 48 hours prior for experimental protocol to minimize if any of non-specific stress. All the protocols and the experiments were conducted in strict compliance according to ethical principles of CPCSEA, Newdelhi and the protocol was approved by the Institutional Animal Ethics Committee, East West College of Pharmacy, Bangalore (Ref No.: EWCP/CPCSEA/IAEC/I/2018/09).

\section{Evaluation of antiulcer activity of ethanol extract}

The ethanol extract of Nymphaea nauchali was evaluated against stress and aspirin induced ulcers and study design in both studies consisting of six groups of six animals in each group as follows.

\begin{tabular}{|c|c|}
\hline Groups & Treatment \\
\hline $\begin{array}{l}\text { Group } \\
\text { Normal }\end{array}$ & Treated with Normal Saline $(2 \mathrm{ml} / \mathrm{kg})$ \\
\hline $\begin{array}{l}\text { Group } \\
\text { Vehicle } \\
\text { control }\end{array}$ & $\begin{array}{l}\text { Induced with ulcers and treated with } 2 \% \\
\text { tween } 20\end{array}$ \\
\hline $\begin{array}{l}\text { Group III: } \\
\text { Standard }\end{array}$ & $\begin{array}{l}\text { Induced with ulcers+ Treated with } \\
\text { omeprazole }(10 \mathrm{mg} / \mathrm{kg}, \text { p.o. })\end{array}$ \\
\hline $\begin{array}{l}\text { Group IV: } \\
\text { EENN } \\
(100 \mathrm{mg} / \mathrm{kg})\end{array}$ & $\begin{array}{l}\text { Induced with ulcers+ Treated with } \\
\text { ethanol extract of Nymphaea nauchali } \\
(100 \mathrm{mg} / \mathrm{kg} \mathrm{p.o)}\end{array}$ \\
\hline $\begin{array}{l}\text { Group V: } \\
\text { EENN } \\
(200 \mathrm{mg} / \mathrm{kg})\end{array}$ & $\begin{array}{l}\text { Induced with ulcers+ Treated with } \\
\text { ethanol extract of Nymphaea nauchali } \\
\text { (200 mg/ kg p.o) }\end{array}$ \\
\hline $\begin{array}{l}\text { Group VI: } \\
\text { EENN } \\
(400 \mathrm{mg} / \mathrm{kg})\end{array}$ & $\begin{array}{l}\text { Induced with ulcers + Treated with } \\
\text { ethanol extract of Nymphaea nauchali } \\
(400 \mathrm{mg} / \mathrm{kg} \mathrm{p.o)}\end{array}$ \\
\hline
\end{tabular}

\section{Evaluation of anti-ulcer activity against aspirin ulcers}

All the experimental animals were kept for overnight fasting and gastric ulcers were by administering cold absolute aspirin (150 mg/kg p.o). All the extract (EENN) and standard drug omeprazole were administered orally prior to the administration of aspirin. One hour later, the animals were sacrificed by cervical dislocation and the stomachs were removed. Gastric acid was collected and its $\mathrm{pH}$ and total acidity was determined. Stomachs were opened along the greater curvature and gently rinsed with water for subsequent scanning. The number of ulcers was scored and percentage of protection and ulcer index were calculated $^{13,14,15}$.

\section{Evaluation of anti-ulcer activity against stress ulcers}

After 12 hour of fasting, EENN and standard drug omeprazole were administered to respective group of experimental rats orally. One hour after treatment, all the rats received $1 \mathrm{ml}$ of $99.5 \%$ ethanol to induce gastric ulcer. One hour later, the animals were sacrificed by cervical dislocation and the stomachs were removed. Gastric acid was collected and its $\mathrm{pH}$ and total acidity was determined. Stomachs were opened along the greater curvature and gently rinsed with water for subsequent scanning. The number of ulcers was scored and percentage of protection and ulcer index were calculated and $\mathrm{pH}$ were estimated ${ }^{13,16}$.

\section{Statistical Analysis}

The data obtained from the present investigation were analyzed by ANOVA followed by post hoc Dunnet's t-test with the help of Graphpad prism5 software. All the values were shown as mean \pm standard error of mean (S.E.M.). 


\section{RESULTS AND DISCUSSION}

\section{Preliminary phytochemical study}

The percentage yield of the EENN was found to be $9.15 \%$ $\mathrm{w} / \mathrm{w}$. The preliminary phytochemical investigation of the ethanol extract of Nymphaea nauchali reveals the presence of alkaloids, glycosides, poly phenols, flavonoids, tannins, steroids, and carbohydrates in the plant.

\section{Evaluation of antiulcer activity}

The etiological factors that causes ulcer in human being are several which includes alcohol, stress, chronic use of antiinflammatory drugs and continuous alcohol ingestion, spicy food among others. In most of the cases, the exact causative factor of ulcer is unknown but it is generally accepted that it is the result of an imbalance between aggressive factors and defensive factors that maintenance mucosal integrity through the several endogenous mechanisms. Peptic ulcer is leading cause of mortality and morbidity in developing countries, characterized by imbalance between aggressive gastric luminal factor and defensive mucosal barrier. This disease is mainly associated with increase in gastric acid secretion. Numerous factors like diet, smoking, drugs like aspirin and infection are responsible for augmentation of ulcers. Still, no therapeutic intervention has been found successful. So, in the present study efforts has been made to review and to explore various animal models to find out a suitable medication for the treatment of peptic ulcer ${ }^{17,18,19}$.

Nymphaea nauchali are employed in the treatment and management of the ulcers in folklore medicine but still no complete curative treatment is available. So this review has been designed to explore the effects of Nymphaea nauchali extracts for the treatment of peptic ulcer against various ulcer models like pyloric ligation; ethanol and aspirin induced ulcer models.
In the present study, oral administration of ethanol extract Nymphaea nauchali at $200 \mathrm{mg} / \mathrm{kg}$ and $400 \mathrm{mg} / \mathrm{kg}$ significantly inhibited gastric ulcer formation in both selected ulcer models when compared control and effect was comparable to standard omeprazole.

Aspirin is commonly used for inducing ulcer in experimental rats' due to its intense gastric mucosal damage. Studies suggest that the Aspirin damage to the gastrointestinal mucosa starts with micro vascular injury, namely disruption of the vascular endothelium resulting in increased vascular permeability, edema formation and

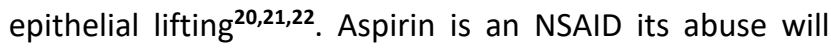
induce gastric ulceration by inhibition of gastric cyclooxygenase resulting in the formation of prostacyclin, which is predominant prostanoid produced in the gastric mucosa. The ulcers produced can be prevented by exogenous $\mathrm{PGE}_{2}$ and $\mathrm{PGI}_{2}$. The alcohol is another agent produces irritation in stomach develops ulcers. in the stomach due to free radical nature ${ }^{23,24}$.

The ethanol extract of Nymphaea nauchali was tested using aspirin and ethanol induced ulcers in albino wistar rats model. The results are as follows.

\section{Antiulcer activity against aspirin induced ulcers}

Administration of aspirin has shown significant $(P<0.001)$ no of ulcers and ulcer index in vehicle control animals in the present study compare to normal animals which have shown no ulcers and ulcer index. Administration of Standard drug omeprazole and EENN at medium and high dose have significantly $(P<0.01)$ reduced number of ulcers formed and ulcer index when compare to vehicle control. Due to the reduction in number of ulcers and ulcer index, percentage of protection was significantly increased in therapeutic groups treated with standard drug and EENN [Table No.:1]

Table 1: Effect of ethanol extract of Nymphaea nauchali on Aspirin induced ulcers in albino wistar rats

\begin{tabular}{|c|c|c|c|c|c|c|c|}
\hline Group & $\begin{array}{c}\text { Number of } \\
\text { ulcers }\end{array}$ & Ulcer Index & $\begin{array}{c}\text { Percentage } \\
\text { of } \\
\text { inhibition }\end{array}$ & $\begin{array}{c}\text { Percentage } \\
\text { of Ulcerated } \\
\text { Area }\end{array}$ & $\begin{array}{c}\text { Percentage } \\
\text { of Protected } \\
\text { Area }\end{array}$ & $\mathrm{pH}$ & $\begin{array}{l}\text { Total } \\
\text { Acidity }\end{array}$ \\
\hline Group I: Normal & 0 & 00 & 100 & 0 & 100 & $\begin{array}{l}3.730 \pm \\
0.1046\end{array}$ & $\begin{array}{l}40.90 \pm \\
0.6699\end{array}$ \\
\hline Group II: Ulcer control & $\begin{array}{c}6.333^{+++} \pm \\
0.5578\end{array}$ & $\begin{array}{c}29.80^{+++} \pm \\
1.531\end{array}$ & 0 & $\begin{array}{c}70.45^{+++} \pm \\
1.360\end{array}$ & $29.55^{+++}$ & $\begin{array}{c}1.922^{+++} \pm \\
0.08109\end{array}$ & $\begin{array}{c}73.01^{+++} \pm \\
1.395\end{array}$ \\
\hline $\begin{array}{l}\text { Group III: Standard } \\
\text { (Omeprazole } 10 \\
\mathrm{mg} / \mathrm{kg} \text { ) }\end{array}$ & $\begin{array}{c}1.667^{* * *} \pm \\
0.2108\end{array}$ & $\begin{array}{c}4.275^{* * *} \pm \\
0.4232\end{array}$ & $73.678^{* * *}$ & $\begin{array}{c}21.58^{* * * \pm} \\
1.416\end{array}$ & $78.45^{* * *}$ & $\begin{array}{c}3.852^{* * * \pm} \\
0.1403\end{array}$ & $\begin{array}{c}42.75^{* * *} \pm \\
1.102\end{array}$ \\
\hline $\begin{array}{l}\text { Group IV: EENN } \\
(100 \mathrm{mg} / \mathrm{kg})\end{array}$ & $\begin{array}{l}4.667 \pm \\
0.4216\end{array}$ & $\begin{array}{c}22.72 \pm \\
1.515\end{array}$ & 26.306 & $\begin{array}{c}52.38 \pm \\
1.433\end{array}$ & 47.42 & $\begin{array}{c}2.118 \pm \\
0.04915\end{array}$ & $\begin{array}{c}56.71 \pm \\
1.771\end{array}$ \\
\hline $\begin{array}{l}\text { Group V: EENN } \\
(200 \mathrm{mg} / \mathrm{kg})\end{array}$ & $\begin{array}{c}2.333^{* *} \pm \\
0.2108\end{array}$ & $\begin{array}{c}17.08^{* *} \pm \\
1.173\end{array}$ & $63.161^{* *}$ & $\begin{array}{c}41.48^{* *} \pm \\
0.6586\end{array}$ & $58.52 * *$ & $\begin{array}{c}3.548^{* * *} \pm \\
0.06877\end{array}$ & $\begin{array}{c}48.99 * * * \pm \\
1.292\end{array}$ \\
\hline $\begin{array}{l}\text { Group VI: EENN } \\
(400 \mathrm{mg} / \mathrm{kg})\end{array}$ & $\begin{array}{c}1.667^{* * *} \pm \\
0.3333\end{array}$ & $\begin{array}{c}4.468^{* * *} \pm \\
0.4937\end{array}$ & $73.678^{* * *}$ & $\begin{array}{c}25.10^{* * *} \pm \\
1.318\end{array}$ & $74.9 * * *$ & $\begin{array}{c}3.932^{* * *} \pm \\
0.1771\end{array}$ & $\begin{array}{c}40.87^{* * *} \pm \\
0.6475\end{array}$ \\
\hline
\end{tabular}

Values are mean \pm S.E.M, $n=6$ symbols represent statistical significance.; $n s p>0.05, * p<0.05, * * p<0.01, * * * p<0.001$ vs ulcer control.; ns $p>0.05,+p<0.05,++p<0.01,+++p<0.001$ normal control vs Normal control. 
Table 2: Effect of ethanol extract of Nymphaea nauchali on ethanol induced ulcers in albino wistar rats

\begin{tabular}{|c|c|c|c|c|c|c|c|}
\hline Group & $\begin{array}{c}\text { Number of } \\
\text { ulcers }\end{array}$ & Ulcer Index & $\begin{array}{c}\text { Percentage } \\
\text { of } \\
\text { inhibition }\end{array}$ & $\begin{array}{c}\text { Percentage } \\
\text { of Ulcerated } \\
\text { Area }\end{array}$ & $\begin{array}{c}\text { Percentage } \\
\text { of Protected } \\
\text { Area }\end{array}$ & $\mathrm{pH}$ & $\begin{array}{l}\text { Total } \\
\text { Acidity }\end{array}$ \\
\hline Group I: Normal & 0 & 00 & 100 & 0 & 100 & $\begin{array}{c}3.838 \pm \\
0.09243\end{array}$ & $\begin{array}{l}41.95 \pm \\
0.6871\end{array}$ \\
\hline Group II: Ulcer control & $\begin{array}{c}6.833^{+++} \pm \\
0.4014\end{array}$ & $\begin{array}{c}28.07^{+++} \pm \\
1.878\end{array}$ & 00 & $\begin{array}{c}70.19^{+++} \pm \\
1.137\end{array}$ & $29.81^{+++}$ & $\begin{array}{c}1.840^{+++} \pm \\
0.08937\end{array}$ & $\begin{array}{c}74.87^{+++} \pm \\
2.251\end{array}$ \\
\hline $\begin{array}{l}\text { Group III: Standard } \\
\text { (Omeprazole } 10 \\
\text { mg/kg) }\end{array}$ & $\begin{array}{c}1.667^{* * * \pm} \\
0.2108\end{array}$ & $\begin{array}{c}4.347^{* * * \pm} \\
0.4574\end{array}$ & $75.603 * * *$ & $\begin{array}{c}23.98^{* * * \pm} \pm \\
1.764\end{array}$ & $76.02 * * *$ & $\begin{array}{c}3.660 * * * \pm \\
0.1807\end{array}$ & $\begin{array}{c}41.41^{* * *} \pm \\
0.8697\end{array}$ \\
\hline $\begin{array}{l}\text { Group IV: EENN } \\
(100 \mathrm{mg} / \mathrm{kg})\end{array}$ & $\begin{array}{l}5.667 \pm \\
0.5578\end{array}$ & $\begin{array}{c}23.16 \pm \\
1.471\end{array}$ & 17.064 & $\begin{array}{c}52.47 \pm \\
1.442\end{array}$ & 47.53 & $\begin{array}{c}2.105 \pm \\
0.05566\end{array}$ & $\begin{array}{c}62.09 \pm \\
2.352\end{array}$ \\
\hline $\begin{array}{l}\text { Group V: EENN } \\
(200 \mathrm{mg} / \mathrm{kg})\end{array}$ & $\begin{array}{c}2.833^{* * * \pm} \\
0.1667\end{array}$ & $\begin{array}{c}15.37^{* *} \pm \\
0.8181\end{array}$ & $58.53 * *$ & $\begin{array}{c}40.92^{* *} \pm \\
0.8928\end{array}$ & $59.08 *$ & $\begin{array}{c}3.442 * * \pm \\
0.07359\end{array}$ & $\begin{array}{c}50.16^{* *} \pm \\
1.068\end{array}$ \\
\hline $\begin{array}{l}\text { Group VI: EENN } \\
(400 \mathrm{mg} / \mathrm{kg})\end{array}$ & $\begin{array}{c}1.833^{* * * \pm} \\
0.3073\end{array}$ & $\begin{array}{c}4.510^{* * * \pm} \pm \\
0.4332\end{array}$ & $73.174 * * *$ & $\begin{array}{c}25.77^{* * *} \pm \\
1.324\end{array}$ & 74.23 & $\begin{array}{c}3.987^{* * * \pm} \pm \\
0.1202\end{array}$ & $\begin{array}{c}39.33^{* * *} \pm \\
1.023\end{array}$ \\
\hline
\end{tabular}

Values are mean \pm S.E.M, $n=6$ symbols represent statistical significance.; ns $p>0.05, * p<0.05, * * p<0.01, * * * p<0.001$ vs ulcer control.; ns $p>0.05,+p<0.05,++p<0.01,+++p<0.001$ normal control vs Normal control.

The formation of significant ulcerated area was observed and total acidity was significantly increased in vehicle control animals due to the administration of aspirin. But there was significant $(P<0.001)$ decrease in ulcerated area and total acidity found in omeprazole and EENN $(200 \mathrm{mg} / \mathrm{kg}$ and $400 \mathrm{mg} / \mathrm{kg}$ ) treated animals compare to vehicle control group. Hence the percentage of protected area was significantly increased in animals treated with omeprazole and EENN [Table No.:1]

\section{Anti- ulcer activity against ethanol induced ulcers}

In the present study of ethanol induced ulcer model, control animals have shown significant $(P<0.001)$ no of ulcers and ulcer index compare to normal animals which have shown no ulcers and ulcer index. Administration of Standard drug omeprazole and EENN at medium and high dose have significantly $(P<0.001)$ reduced number of ulcers formed and ulcer index when compare to vehicle control. Due to the reduction in number of ulcers and ulcer index, percentage of protection was significantly increased in therapeutic groups treated with standard drug and EENN. Effect of EENN at $100 \mathrm{mg} / \mathrm{kg}$ was not significant [Table No.:2]

The significant increase in formation of ulcerated area and total acidity were observed in vehicle control animals due to stress. But there was significant $(P<0.001)$ decrease in ulcerated area and total acidity found in omeprazole and EENN $(200 \mathrm{mg} / \mathrm{kg}$ and $400 \mathrm{mg} / \mathrm{kg})$ treated animals compare to vehicle control group. Hence the percentage of protected area was significantly increased in animals treated with omeprazole and EENN [Table No.:2].

In the present study, significant decrease in gastric ulcer, ulcer index, ulcerated area and total acidity was observed animals in pretreated ethanol extract compared to vehicle control group. In the present study we also found that there is significant rise percentage inhibition of ulcer formation, protected area and $\mathrm{pH}$ of gastric content. The antiulcer potentials of plant extracts were almost similar to standard drug omeprazole used in the present study.

The other ulcerogenic agents alcohol and aspirin used in the present study directly irritate GIT mucosa and acts as free radical results in the formation of peptic ulcers. Hence the drugs those possess antioxidants can be good approaches for the treatment of ulcers due to the presence flavonoids and phenolic compounds. In this regard, the study can be performed to evaluate the antioxidant properties of the plant to determine the possible mechanism ${ }^{\mathbf{2 5}, 26}$.

The ethanol extract of Nymphaea nauchali possess significant antiulcer property against stress and aspirin induced ulcers. The further investigation should be performed to isolate and evaluate specific constituents responsible for antiulcer activity.

\section{CONCLUSION}

The present study was undertaken for the investigation of antiulcer activity of ethanol extracts of Nymphaea nauchali against stress and aspirin induced ulcers in animal model. From the results obtained from the study, it can be concluded that ethanol extract of the plant exhibited a strong gastroprotective activity against experimentally induced ulcers. However further investigation required establishing the clear mechanism of action of the extract and also to isolate individual phytoconstituents present in Nymphaea nauchali that may be responsible for these beneficial therapeutic effects.

Acknowledgements: The authors of manuscript are thankful to The Principal and management of East West College of Pharmacy, Bangalore for providing facilities to conduct this research work. 


\section{REFERENCES}

1. Hussain L, Akash MS, Naseem S, et al. Anti-Ulcerogenic effects of Salmalia malabarica in gastric ulceration - Pilot Study. Adv Clin Exp Med 2015;24:595-605.

2. Malfertheiner P, Chan FK, McColl KE. Peptic ulcer disease. Lancet 2009;374:1449-61.

3. Scanlon VC and Sanders T. Essential of Anatomy and Physiology, $5^{\text {th }}$ Edn., F. A. Davis company, Philadelphia, 2007, 396.

4. Toma W, Hiruma-Lima CA, Guerrero RO, Souza Brito AR. Preliminary studies of Mammea Americana $L$ (Guttiferae) bark/latex extract point to an effective antiulcer effect on gastric ulcer models in mice. Phytomedicine 2005;12:34550 .

5. Al-Yahya MA, Rafatullah S, Mossa JS, Ageel AM, Al-Said MS, Tariq M. Gastric antisecretory, antiulcer and cytoprotective properties of ethanol extract of Alpinia galanga willd in rats. Phytotherapy Research 1990;4:112-4.

6. Santin JR, Lemos M, Júnior LCK, Niero R, de Andrade SF. Antiulcer effects of Achyrocline satureoides (Lam.) DC (Asteraceae) (Marcela), a folk medicine plant, in different experimental models. Journal of Ethnopharmacology. 2010;130(2):334-6.

7. Saldanha CJ, Singh BG, Leguminosae, In: Saldanha C.J. (Ed.) Flora of Karnataka Vol:I, Oxford and IBH, 1984, 495-9.

8. Mohan Maruga Raja MK, Neeraj Kumar S, and Mishra SH. A comprehensive review on Nymphaea stellata: A traditionally used bitter. J Adv Pharm Technol Res. 2010;1(3):311-9.

9. Manjeet $S$ and Alok PJ. A review on genus Nymphaea: multipotential medicinal plant. Asian J Pharm Edu \& Res 2017;6(4):1-9.

10. Priyabrata $P$, Sridhar $S$, Bainateya $M$ and Sudhir KP. Anthelmintic and Preliminary Phytochemical Screening of Nymphaea nouchali Burm.f. Against Intestinal Helminthiasis. Res J Pharm \& Technol 2009;2(3):537-9.

11. Kokate CK. Practical Pharmacognosy. New Delhi; Vallabh Prakashan: 1994;4:100-114.

12. KR Khandelwal, Practical Pharmacognosy-Techniques and Experiments .Pune; NiraliPrakashan; 2000.
13. Vogel H. Drug Discovery and Evaluation Pharmacological Assays.2 ${ }^{\text {nd }}$ Edition 2002. New York: Springer-Verlag Berlin Heidelberg :870-75.

14. Aitken J, Fisher $\mathrm{H}$. Reactive oxygen species generation and human spermatozoa. The balance of benefit and risk. Bioassays 1994; 16:259-67.

15. Rasika DB, Mahendra A, Sneha JA, Subodh CP. Antiulcer activity of the ethanol extract of leaves of Sesbania grandiflora (linn.) Int J Pharm Pharmaceut Sci 2010;2(4): 206-08.

16. Vanita $\mathrm{K}$ and Deepali M. Evaluation of antipyretic and antiulcer activity of ethanolic extract of leaves of Alstonia scholaris I. in albino wistar rats. Asian J Pharm Clin Res, 2012;12(12): 203-8.

17. Van JR. Inhibition of prostaglandin synthesis as a mechanism of action of aspirin-like drugs. Nature 1971; 235: 231-5.

18. Szabo S, Trier JS, Brown A, Schnoor J. Early vascular injury and increased vascular permeability in gastric mucosal injury caused by ethanol in the rat. Gastroenterology 1985; 88: 228-236.

19. Konturek SJ, Piastucki, Brzozwski T, Radecki T, Dembinska KA, Zmuda A, Gryglewski R. Role of prostaglandins in the formation of Aspirin induced gastric ulcers. Gastroenterology 1979; 80: 4-9.

20. Schubeer MI. Pharmacotherapy for acid/peptic disorders. Yale J Biol. Med 1996; 69: 197-201.

21. Bhattacharya SK, Bhattacharya A, Kumar A, Ghosal S: Antioxidant activity of Bacopa moniera in rat frontal cortex, striatum and hippocampus. Phytother Res 2000; 14: 1-6.

22. Ch. V Rao, Ojha SK, Radhakrishnan K, Govindarajan R, Rastogi S, Mehrotra S, Pushpagandan P. Antiulcer activity of Utleria salcifolia rhizome extract. J Ethannopharmacol 2004; 91: 243-9.

23. Cochran T, Stefanko J, Moore C, Saik R. Dimethyl sulfoxide protection against gastric stress ulceration. Cur Surg 1983; 40: 435-7.

24. Kunchady E.Oxygen radical scavenging activity of curcumin. Int J Pharmacol 1990; 58: 237-40.

25. Malfertheiner P, Chan FK, McColl KE. Peptic ulcer disease. Lancet 2009;374:1449-61.

26. Govindarajan R. Studies on antioxidant activities of Desmodium gangaticum Biol Pharm Bull 2003; 26: 1424-7.

Source of Support: The author(s) received no financial support for the research, authorship, and/or publication of this article.

Conflict of Interest: The author(s) declared no potential conflicts of interest with respect to the research, authorship, and/or publication of this article.

For any question relates to this article, please reach us at: editor@globalresearchonline.net New manuscripts for publication can be submitted at: submit@globalresearchonline.net and submit_ijpsrr@rediffmail.com 